\title{
Inheritance of Cracking and Scarring in Pepper Fruit
}

\author{
Deborah Johnson'1 and Dean E. Knavel \\ Department of Horticulture and Landscape Architecture, University of Kentucky, \\ Lexington, $K Y 40546$ \\ Additional index words. Capsicum annuum, gene effects
}

\begin{abstract}
Cracking and scarring of pepper (Capsicum annuum L.) fruit are under genetic control in families having the cultivar Serrano Chili as the $P_{1}$ parent. Fruit of 'Serrano Chili' exhibited slight cuticle cracking or scarring, with no wall cracking, for an average rating of 2.2. Fruit cracking ratings of the $P_{2}$ parents ('Anaheim Chili', 'Red Cherry Small', and 'Keystone Resistant Giant') were 1.0, 1.0, and 1.8, respectively, whereas ratings for F, ('Serrano Chili' × 'Anaheim Chili'), F ('Serrano Chili' x 'Red Cherry Small'), and F, ('Serrano Chili' x 'Keystone Resistant Giant') were 3.5, 2.8, and 3.5, respectively-an indication of overdominance. Cracking ratings in $\mathrm{F}_{2}$ and $\mathrm{BCP}_{2}$ populations were very similar and shifted toward the mean of the $P_{2}$ parent within each family, while ratings in the $B_{C} P_{1}$ populations were similar to the $F_{1}$ mean. Estimates of gene effects for cracking were mostly dominant, with some additive effects in 'Serrano Chili' $x$ 'Anaheim Chili' and 'Serrano Chili' $\times$ 'Keystone Resistant Giant' families, and additive $x$ additive epistasis in 'Serrano Chili' 'Keystone Resistant Giant'. Plants selected from segregating generations for either high and low scarring or high and low cracking produced progeny the following year with lower ratings than their respective mother's rating the previous year. Since cracking and scarring were significantly correlated with length, diameter, and length : diameter ratio of fruit in only a few generations and in segregating progeny of selected plants, fruit shape has minimal relationship to cracking and scarring.
\end{abstract}

Fruit cracking in pepper is not a serious commercial problem, but slight cuticular scarring is common in the jalapeno type. Setiamihardji (1982) observed in a pepper fruit detachment study that fruit cracking and/or scarring were more severe in certain generations and more severe within some families than in others. Scarred fruit showed splitting of the cuticle, and, in cracked fruit, cracks extended through the wall and into the locule area. Scarring and cracking occurred primarily longitudinally from near the apex and ranged from a few millimeters to the entire length of the fruit.

Published data on fruit cracking and/or scarring are limited, but it was reported that cultivars of tomato differ in fruit cracking (Frazier, and Bowers, 1947; Reynard, 1960). Fruit cracking in apple was attributed to uneven growth (Skene, 1980), and small fruit rarely cracked (Shutak and Schrader, 1948).

The objectives of this study with pepper were to determine: a) if fruit cracking and scarring were under genetic control, b) if they were correlated with fruit shape, and c) the ease of developing genotypes without cracking and scarring.

The cultivars selected as parents had diverse fruit lengths and diameters. 'Serrano Chili' bore fruit that averaged $40 \mathrm{~mm}$ long and $13 \mathrm{~mm}$ in diameter, with slight cuticle cracking or scarring. 'Anaheim Chili' bore smooth fruit that averaged $174 \mathrm{~mm}$ long and $33 \mathrm{~mm}$ in diameter. 'Red Cherry Small' bore smooth fruit that averaged $22 \mathrm{~mm}$ long and $29 \mathrm{~mm}$ in diameter. 'Keystone Resistant Giant' bore slightly scarred, bell-shaped fruit that averaged $79 \mathrm{~mm}$ long and $69 \mathrm{~mm}$ in diameter.

Parental plants were selfed for two generations in the greenhouse before crossing to produce the following three families: 'Serrano Chili' x 'Anaheim Chili'; 'Serrano Chili' x 'Red Cherry Small'; and 'Serrano Chili' $\times$ 'Keystone Resistant Giant'. Setiamihardja (1982) found that reciprocal $F_{1}$ hybrids of the parents produced similar fruit characteristics. The $\mathrm{F}_{1}, \mathrm{~F}_{2}, \mathrm{BCP}_{1}$,

Received for publication 23 Dec. 1988. This Kentucky Agricultural Experiment Station paper (88.10.305) is published by permission of the Director. Part of a thesis submitted by D.J. in partial fulfillment of the requirements for a MS degree at Univ. of Kentucky.

'Present address: Dept. of Agriculture and Natural Resources, Morehead State Univ., Morehead, KY 40546-0091. and $\mathrm{BCP}_{2}$ generations were produced by crossing and selfing plants in the greenhouse. Unpollinated flowers were removed during the crossing period to prevent contamination.

For each of the two years (1981 and 1982) of this study, seedlings were grown in the greenhouse and set into the field in mid-May. The first year planting consisted of both parents, $\mathrm{F}_{1}, \mathrm{~F}_{2}, \mathrm{BCP}_{1}$, and $\mathrm{BCP}_{2}$ of each family. The experiment was a split-plot treatment arrangement in a randomized complete-block

Table 1. Fruit cracking means, rating distribution, and total number of progeny rated for parents and generations of pepper families.

\begin{tabular}{|c|c|c|c|c|c|c|c|}
\hline \multirow[b]{2}{*}{ Generation } & \multirow{2}{*}{$\begin{array}{c}\text { Cracking } \\
\text { mean }\end{array}$} & \multicolumn{5}{|c|}{$\begin{array}{l}\text { Progeny distribution } \\
\text { (\% rating })^{2}\end{array}$} & \multirow{2}{*}{$\begin{array}{c}\text { Total no. } \\
\text { progeny rated }\end{array}$} \\
\hline & & 1 & 2 & 3 & 4 & 5 & \\
\hline \multicolumn{8}{|c|}{ 'Serrano Chili' $\times$ 'Anaheim Chili' } \\
\hline$P_{1}$ & 2.13 & 3 & 80 & 17 & 0 & 0 & 34 \\
\hline $\mathrm{P}_{2}$ & 1.00 & 100 & 0 & 0 & 0 & 0 & 34 \\
\hline $\mathrm{F}_{1}$ & 3.52 & 0 & 7 & 47 & 33 & 13 & 34 \\
\hline$F_{2}$ & 1.96 & 52 & 18 & 18 & 6 & 6 & 210 \\
\hline $\mathrm{BCP}_{1}$ & 2.82 & 13 & 24 & 40 & 14 & 9 & 140 \\
\hline $\mathrm{BCP}_{2}$ & 1.80 & 54 & 21 & 17 & 7 & 1 & 140 \\
\hline $\mathrm{LSD}_{0.05}$ & 0.54 & & & & & & \\
\hline \multicolumn{8}{|c|}{ 'Serrano Chili' $x$ 'Red Cheny Small' } \\
\hline$P_{1}$ & 2.20 & 0 & 80 & 20 & 0 & 0 & 34 \\
\hline $\mathrm{P}_{2}$ & 1.00 & 100 & 0 & 0 & 0 & 0 & 34 \\
\hline $\mathrm{F}_{1}$ & 2.83 & 0 & 47 & 33 & 10 & 10 & 34 \\
\hline$F_{2}$ & 2.01 & 44 & 24 & 22 & 7 & 3 & 210 \\
\hline $\mathrm{BCP}_{1}$ & 2.71 & 14 & 38 & 23 & 13 & 12 & 140 \\
\hline $\mathrm{BCP}_{2}$ & 1.83 & 26 & 20 & 22 & 9 & 3 & 140 \\
\hline $\operatorname{LSD}_{0.05}$ & 0.58 & & & & & & \\
\hline \multicolumn{8}{|c|}{ 'Serrano Chili' x 'Keystone Resistant Giant' } \\
\hline $\mathbf{P}_{1}$ & 2.14 & 0 & 86 & 14 & 0 & 0 & 34 \\
\hline $\mathrm{P}_{2}$ & 1.80 & 20 & 80 & 0 & 0 & 0 & 34 \\
\hline $\mathrm{F}_{1}$ & 3.49 & 0 & 0 & 54 & 43 & 3 & 34 \\
\hline $\mathrm{F}_{2}$ & 2.39 & 23 & 33 & 29 & 11 & 4 & 210 \\
\hline $\mathrm{BCP}_{1}$ & 3.16 & 7 & 25 & 28 & 25 & 15 & 140 \\
\hline $\mathrm{BCP}_{2}$ & 2.15 & 23 & 49 & 21 & 4 & 3 & 140 \\
\hline $\mathrm{LSD}_{0.05}$ & 0.21 & & & & & & \\
\hline
\end{tabular}

${ }^{2}$ Rating scale of 1 to 5 with $1=$ no cracking. 
Table 2. Estimates of genetic components and $t$ values for testing genetic effects for fruit cracking in three pepper families in 1981.

\begin{tabular}{|c|c|c|c|c|c|c|}
\hline \multirow{2}{*}{$\begin{array}{l}\text { Genetic } \\
\text { component }\end{array}$} & \multicolumn{2}{|c|}{$\begin{array}{l}\text { 'Serrano Chili' X } \\
\text { 'Anaheim Chili' }\end{array}$} & \multicolumn{2}{|c|}{$\begin{array}{l}\text { 'Serrano Chili' } x \\
\text { 'Red Cherry Small' }\end{array}$} & \multicolumn{2}{|c|}{$\begin{array}{c}\text { 'Serrano Chili' x } \\
\text { 'Keystone Resistant Giant' }\end{array}$} \\
\hline & Genetic effect ${ }^{2}$ & $t$ value & Genetic effect ${ }^{2}$ & $t$ value & Genetic effect ${ }^{z}$ & $t$ value \\
\hline Mean (m) & 1.40 & $46.67^{* *}$ & 1.43 & $47.67^{* *}$ & 1.55 & $34.68 * *$ \\
\hline Additive (d) & 0.24 & $3.54^{*}$ & 0.24 & 1.12 & 0.44 & $4.59^{*}$ \\
\hline Dominance $(\mathrm{h})$ & 0.91 & $4.28^{* *}$ & 0.67 & $2.94^{*}$ & 0.86 & $3.11 *$ \\
\hline Additive $\mathrm{x}$ additive (i) & 0.38 & 2.10 & 0.24 & 1.33 & 0.40 & $6.42^{* *}$ \\
\hline Additive $x$ dominance $(j)$ & 0.01 & 0.14 & 0.01 & 0.15 & 0.38 & $3.68^{*}$ \\
\hline Dominance $x$ dominance (1) & 0.02 & 0.05 & -0.40 & -0.90 & -0.49 & -1.07 \\
\hline
\end{tabular}

${ }^{z}$ Transformed values by square root of actual data.

$\because *$ Significant at $P=0.05$ or 0.01 , respectively.

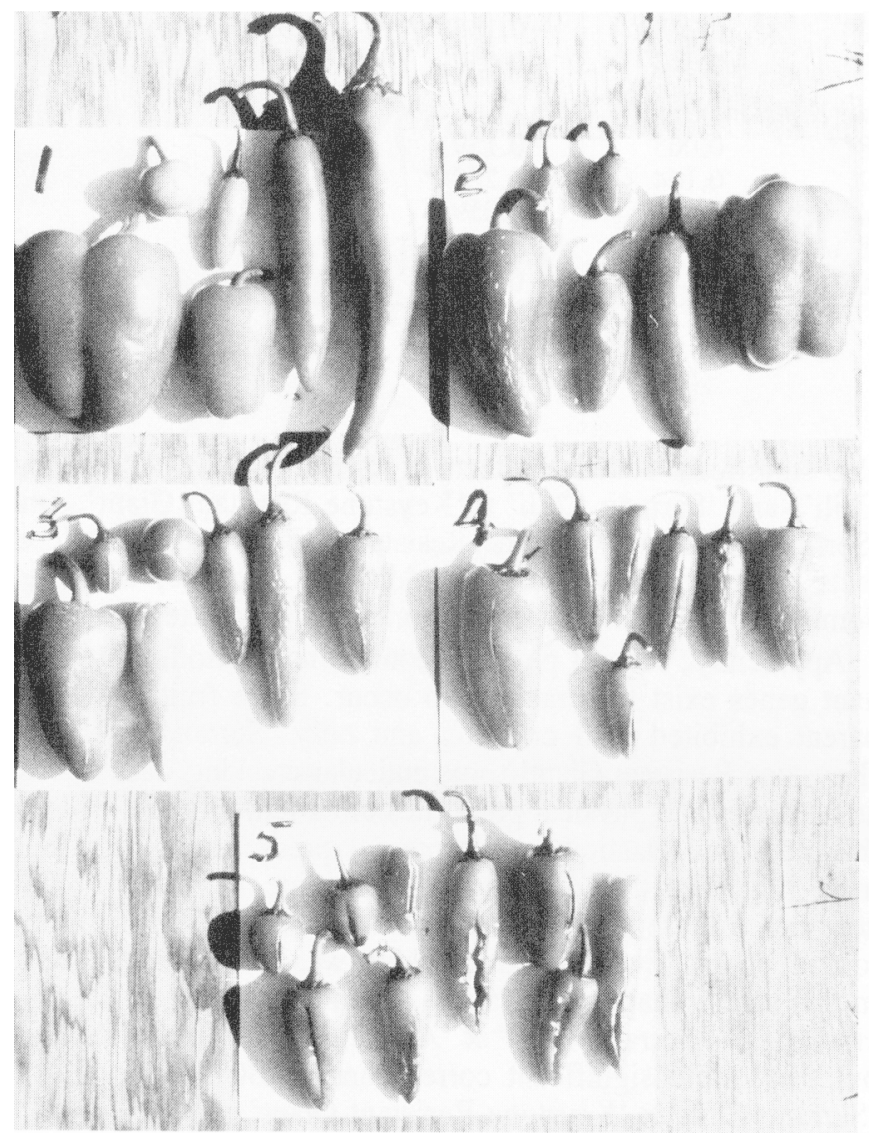

Fig. 1. Pepper fruit cracking ratings $(1=$ no cracking, $5=$ severe wall cracking).

design with three replications. Whole plots consisted of the three families, and subplots consisted of the six generations. There were 36 plants of each parent and $\mathrm{F}_{1}$, and 72 plants of each $\mathrm{F}_{2}$ and backcross generation for each family in each replication. Cultural practices were according to recommendations for growing peppers in Kentucky (Roberts et al., 1980).

Within the $\mathrm{F}_{2}, \mathrm{BCP}_{1}$, and $\mathrm{BCP}_{2}$ generations of each family, plants representing various fruit cracking and scarring ratings were selected in 1981. The selected plants bore fruit with either cracking or scarring ratings that ranged from 1 to 5 . Seeds were collected from these open-pollinated fruits and 30 progeny plants from each selected mother plant were randomized in each of three replications the following year.
Table 3. Correlation coefficients for fruit length, diameter, and fruit length : diameter ratio with fruit cracking in segregating generations of pepper families in 1981.

\begin{tabular}{|c|c|c|c|}
\hline \multirow[b]{2}{*}{ Generation } & \multicolumn{3}{|c|}{ Correlation coefficients } \\
\hline & Length & Diameter & L:D ratio \\
\hline $\begin{array}{l}\mathrm{F}_{2} \\
\mathrm{BCP}_{1} \\
\mathrm{BCP}_{2}\end{array}$ & $\begin{array}{c}\text { Serrano } C h \\
0.059 \\
-0.184 \\
-0.134\end{array}$ & $\begin{array}{l}\text { Anaheim Ch } \\
-0.062 \\
-0.048 \\
0.110\end{array}$ & $\begin{array}{r}-0.010 \\
-0.171 \\
0.121\end{array}$ \\
\hline $\begin{array}{l}\mathrm{F}_{2} \\
\mathrm{BCP}_{1} \\
\mathrm{BCP}_{2}\end{array}$ & $\begin{array}{c}\text { Serrano Chil } \\
0.199 * * \\
0.105 \\
0.009\end{array}$ & $\begin{array}{c}\text { ed Cherry Sr } \\
-0.038 \\
-0.173^{*} \\
0.042\end{array}$ & $\begin{array}{r}0.177^{*} \\
0.012 \\
-0.029\end{array}$ \\
\hline $\begin{array}{l}\mathrm{F}_{2} \\
\mathrm{BCP}_{1} \\
\mathrm{BCP}_{2}\end{array}$ & $\begin{array}{c}\text { 'Serrano Chili' } \times \\
-0.075 \\
0.445^{* *} \\
-0.461^{* *}\end{array}$ & $\begin{array}{l}\text { one Resistan } \\
-0.067 \\
-0.027 \\
-0.514^{* *}\end{array}$ & $\begin{array}{r}-0.003 \\
0.440^{* *} \\
0.430^{* *}\end{array}$ \\
\hline
\end{tabular}

$\because "$ Significant at $P=0.05$ or 0.01 , respectively.

Fruit cracking and scarring were rated separately and visually on a scale of 1 to 5 for each plant, with $1=$ no cracking or scarring; 2 = either slight cuticle cracking or scarring, but no cracking of the fruit wall; 3 and $4=$ either slight to moderate wall cracking or scarring, respectively, but, for cracked fruit, no crack extended through the fruit wall into the locule, and 5 $=$ either severe cracking or scarring.

Data were collected during September and October in the first year and during August and September the second year on three mature, red fruits per plant that were selected at random. Fruit length was measured with vernier calipers as the distance between fruit attachment to the receptacle and the apex. Fruit diameter was recorded at the maximum width.

Analyses of variance were conducted on fruit data. Correlation analyses were conducted on fruit cracking ratings of individual plants with that plant's mean fruit length, diameter, and length : diameter ratios in 1981, and on individual fruit cracking and scarring ratings with that fruit's length, diameter, and length : diameter ratio for progeny in 1982. Estimates of gene effects for fruit cracking were determined on the 1981 data according to the six-parameter model for components of generation means as presented by Singh and Chaudhary (1979). The approximation of degrees of freedom for each component were calculated according to Satterwaite (1946) and used to test the significance of calculated $t$ valves for each generation mean component.

$\mathrm{F}_{1}$ cracking means were greater than for either parent in all 
Table 4. Correlation coefficients of fruit length, diameter, and length : diameter ratio with cracking and scarring ratings of progeny fruit for pepper families in 1982.

\begin{tabular}{|c|c|c|c|c|c|c|}
\hline \multirow{3}{*}{$\begin{array}{l}\text { Mother plant } \\
\text { generation } \\
\text { selection }\end{array}$} & \multicolumn{6}{|c|}{ Correlation coefficients } \\
\hline & \multicolumn{3}{|c|}{ Cracking } & \multicolumn{3}{|c|}{ Scarring } \\
\hline & Length & Diameter & L:D ratio & Length & Diameter & L:D ratio \\
\hline $\begin{array}{l}\mathrm{F}_{2}-\mathrm{A} \\
\mathrm{F}_{2}-\mathrm{B} \\
\mathrm{F}_{2}-\mathrm{C} \\
\mathrm{F}_{2}-\mathrm{D} \\
\mathrm{BCP}_{1}-\mathrm{A} \\
\mathrm{BCP}_{2}-\mathrm{A}\end{array}$ & $\begin{array}{c}0.116 \\
0.093 \\
-0.067 \\
-0.258^{*} \\
-0.182 \\
0.102\end{array}$ & $\begin{array}{c}\text { 'Serran } \\
0.170 \\
-0.206^{*} \\
0.004 \\
-0.111 \\
-0.071 \\
0.187\end{array}$ & $\begin{array}{c}\text { il' x 'Anahe } \\
-0.186 \\
0.114 \\
-0.068 \\
-0.147 \\
-0.175 \\
-0.084\end{array}$ & $\begin{array}{l}\text { Chili' } \\
-0.100 \\
-0.156 \\
-0.371^{* *} \\
0.073 \\
-0.363^{* *} \\
-0.117\end{array}$ & $\begin{array}{c}0.161 \\
0.001 \\
0.024 \\
0.298^{* *} \\
-0.269^{* *} \\
0.168\end{array}$ & $\begin{array}{l}-0.096 \\
-0.144 \\
-0.322^{* *} \\
-0.167 \\
-0.259^{*} \\
-0.231^{*}\end{array}$ \\
\hline $\begin{array}{l}\mathrm{F}_{2}-\mathrm{A} \\
\mathrm{F}_{2}-\mathrm{B} \\
\mathrm{BCP}_{1}-\mathrm{A} \\
\mathrm{BCP}_{2}-\mathrm{A} \\
\mathrm{BCP}_{2}-\mathrm{B}\end{array}$ & $\begin{array}{l}0.176 \\
0.110 \\
0.128 \\
0.260^{*} \\
0.123\end{array}$ & $\begin{array}{l}\text { 'Serrano } \\
-0.116 \\
-0.136 \\
-0.030 \\
-0.096 \\
-0.231^{*}\end{array}$ & $\begin{array}{c}\text { ' x 'Red } C h \\
0.186 \\
0.171 \\
0.071 \\
0.252^{*} \\
0.208^{*}\end{array}$ & $\begin{array}{c}\text { Small' } \\
0.104 \\
0.043 \\
0.096 \\
0.258^{*} \\
-0.043\end{array}$ & $\begin{array}{c}0.043 \\
0.213^{*} \\
0.041 \\
-0.136 \\
-0.050\end{array}$ & $\begin{array}{c}-0.161 \\
-0.050 \\
0.026 \\
0.293^{* *} \\
-0.023\end{array}$ \\
\hline $\begin{array}{l}\mathrm{F}_{2}-\mathrm{A} \\
\mathrm{F}_{2}-\mathrm{B} \\
\mathrm{BCP}_{1}-\mathrm{A} \\
\mathrm{BCP}_{2}-\mathrm{A} \\
\mathrm{BCP}_{2}-\mathrm{B}\end{array}$ & $\begin{array}{l}-0.032 \\
-0.013 \\
-0.014 \\
-0.113 \\
-0.181\end{array}$ & $\begin{array}{c}\text { 'Serrano Chi } \\
-0.205^{*} \\
-0.062 \\
-0.211^{*} \\
-0.075 \\
-0.165\end{array}$ & $\begin{array}{c}\text { 'Keystone } \\
0.288^{* *} \\
0.032 \\
0.144 \\
-0.058 \\
0.020\end{array}$ & $\begin{array}{c}\text { stant Giant' } \\
0.065 \\
0.164 \\
0.030 \\
-0.179 \\
-0.181\end{array}$ & $\begin{array}{c}-0.159 \\
0.288^{* *} \\
0.059 \\
-0.142 \\
-0.009\end{array}$ & $\begin{array}{r}0.207^{*} \\
-0.061 \\
-0.071 \\
-0.077 \\
-0.175\end{array}$ \\
\hline
\end{tabular}

",*"Significant at $P=0.05$ or 0.01 , respectively.

Table 5. Mean fruit cracking and scarring ratings for selected mother plants in 1981 and their progeny in 1982 for pepper families.

\begin{tabular}{|c|c|c|c|c|}
\hline \multirow[b]{2}{*}{$\begin{array}{l}\text { Plant } \\
\text { selection }\end{array}$} & \multicolumn{2}{|c|}{ Mother fruit (1981) } & \multicolumn{2}{|c|}{ Progeny fruit (1982) } \\
\hline & $\begin{array}{c}\text { Cracking } \\
\text { rating }\end{array}$ & $\begin{array}{c}\text { Scarring } \\
\text { rating }^{\mathrm{z}}\end{array}$ & $\begin{array}{c}\text { Cracking } \\
\text { rating }\end{array}$ & $\begin{array}{l}\text { Scarring } \\
\text { rating }^{2}\end{array}$ \\
\hline \multicolumn{5}{|c|}{ 'Seranno Chili' x 'Anaheim Chili' } \\
\hline $\mathrm{F}_{2}-\mathrm{A}$ & 1 & $N^{y}$ & $1.2 \mathrm{c}^{\mathrm{x}}$ & $1.4 \mathrm{c}$ \\
\hline $\mathrm{F}_{2}-\mathrm{B}$ & 3 & 2 & $2.4 \mathrm{ab}$ & $2.0 \mathrm{a}$ \\
\hline $\mathrm{F}_{2}-\mathrm{C}$ & 5 & 2 & $2.4 \mathrm{ab}$ & $2.1 \mathrm{a}$ \\
\hline $\mathrm{F}_{2}-\mathrm{D}$ & 5 & NR & $2.3 \mathrm{~b}$ & $1.8 \mathrm{~b}$ \\
\hline $\mathrm{BCP}_{1}-\mathrm{A}$ & 5 & NR & $2.6 \mathrm{a}$ & $2.1 \mathrm{a}$ \\
\hline $\mathrm{BCP}_{2}-\mathrm{A}$ & 4 & NR & $1.4 \mathrm{c}$ & $1.2 \mathrm{c}$ \\
\hline \multicolumn{5}{|c|}{ 'Serrano Chili' x 'Red Cherry Small' } \\
\hline $\mathrm{F}_{2}-\mathrm{A}$ & 4 & 1 & $2.2 \mathrm{a}$ & $1.8 \mathrm{~b}$ \\
\hline $\mathrm{F}_{2}-\mathrm{B}$ & 1 & 3 & $2.0 \mathrm{ab}$ & $2.3 \mathrm{a}$ \\
\hline $\mathrm{BCP}_{1}-\mathrm{A}$ & 1 & 1 & $1.1 \mathrm{c}$ & $1.4 \mathrm{c}$ \\
\hline $\mathrm{BCP}_{2}-\mathrm{A}$ & 1 & 1 & $1.7 \mathrm{~b}$ & $1.3 \mathrm{c}$ \\
\hline $\mathrm{BCP}_{2}-\mathrm{B}$ & 3 & NR & $1.8 \mathrm{~b}$ & $1.3 \mathrm{c}$ \\
\hline \multicolumn{5}{|c|}{ 'Serrano Chili' x 'Keystone Resistant Giant' } \\
\hline $\mathrm{F}_{2}-\mathrm{A}$ & 1 & 1 & $1.2 \mathrm{c}$ & $1.4 \mathrm{~d}$ \\
\hline $\mathrm{F}_{2}-\mathrm{B}$ & 1 & 5 & $1.2 \mathrm{c}$ & $3.2 \mathrm{a}$ \\
\hline $\mathrm{BCP}_{1}-\mathrm{A}$ & 5 & NR & $2.4 \mathrm{a}$ & $2.3 \mathrm{~b}$ \\
\hline $\mathrm{BCP}_{2}-\mathrm{A}$ & 1 & 1 & $1.1 \mathrm{c}$ & $1.3 \mathrm{~d}$ \\
\hline $\mathrm{BCP}_{2}-\mathrm{B}$ & 4 & NR & $1.6 \mathrm{~b}$ & $1.8 \mathrm{c}$ \\
\hline
\end{tabular}

${ }^{2}$ Rating of 1 to 5 , with $1=$ no cracking or scarring; $2=$ slight scarring or cuticle cracking; and $5=$ severe wall cracking or scarring.

yNR = not rated.

xMean separation within column within family by Duncan's multiple range test, $P=0.05$.

families (Table 1) —an indication of over-dominance. Estimates of gene effects (Table 2) indicated that dominance effects were the major contributors to conditions for cracking. There were also significant additive effects in 'Serrano Chili' $\times$ 'Anaheim Chili', and 'Serrano Chili' $\times$ 'Keystone Resistant Giant'. Only 'Serrano Chili' $\times$ 'Keystone Resistant Giant' had epistatic effects with significant positive additive $\times$ additive, additive $\times$ dominance, and dominance $\times$ dominance gene effects.

Apparently, several physical conditions controlled by dominant genes exist for cracking to occur. Since fruits of neither parent exhibited wall cracking and only 'Serrano Chili' and 'Keystone Resistant Giant' some cuticular cracking, factors, such as thickness and physical properties of cuticular tissue, cell wall thickness and elasticity, and internal pressures, appear to be more important than fruit shape. Considine and Brown (1981) considered these factors in their theory on cracking as related to fruit shape. Even though cracking was longitudinal (Fig. 1) in this study, shape (fruit ratios) appears to have no relation to cracking in 'Serrano Chili' $\times$ 'Anaheim Chili' fruit (Table 3), but there were significant correlations in $\mathrm{BCP}_{1}$ and $\mathrm{BCP}_{2}$ of 'Serrano Chili' $\times$ 'Keystone Resistant Giant'.

Most cracking correlation coefficients for progeny of selected mother plants grown out in 1982 were nonsignificant (Table 4). Selecting for increased diameter within each family would not increase cracking, and in only one selection of 'Serrano Chili' $\times$ 'Red Cherry Small' was there a significant positive correlation with fruit length.

Lower cracking and scarring ratings for progeny in 1982 than the mother plant's rating in 1981 (Table 5) indicate environmental influence. However, these conditions do not appear to be associated with excess rainfall, which was reported to cause cracking in tomato (Frazier and Bowers, 1947) and cherry (Kertesy and Nebel, 1935; Powers and Bollen, 1947). Total rainfall during the data-recording period was less in 1981 than in 1982, with 140 and $172 \mathrm{~mm}$, respectively.

Scarring or cuticular cracking of pepper fruit appears to be under genetic control, as indicated by higher progeny scarring ratings from selected mother plants that rated 2 or higher than 
progeny ratings from mother plants that rated 1 (Table 4). Apparently, scarring is not a precondition for cracking. Evidence of this is found in $\mathrm{F}_{2}-\mathrm{B}$ of the 'Serrano Chili' $\times$ 'Keystone Resistant Giant' family, where the mother plant with a scarring rating of 5 and a cracking rating of 1 produced progeny with a scarring rating of 3.2 and a cracking rating of 1.2. Conversely, mother plant selection $\mathrm{F}_{2}$-A of 'Serrano Chili' $\times$ 'Red Cherry Small', with a cracking rating of 4 and a scarring rating of 1 , produced progeny with a cracking rating of 2.2 and a scarring rating of 1.8 .

Based on our findings, we would expect that rapid progress should be made in selecting, crossing, and/or backcrossing with crack- and scar-free fruit to develop desired fruit shapes free of cracking and scarring where 'Serrano Chili' would be used as a parent. These conclusions are based on the high percentage of plants recovered in $\mathrm{F}_{2}$ and $\mathrm{BCP}_{2}$ populations with a cracking rating of 1 (Table 1), and the low frequency of significant positive correlation coefficients in 1981 (Table 3) and 1982 (Table 5) progeny. Even though reciprocal $F_{1}$ hybrids produced similarly shaped fruit, the possibility of maternal inheritance in fruit cracking and scarring was not investigated.

\section{Literature Cited}

Considine, J. and K. Brown. 1981. Physical aspects of fruit growth. Plant Physiol. 68:371-376.
Frazier, W.A. and J.L. Bowers. 1947. A final report on studies of tomato fruit cracking in Maryland. Proc. Amer. Soc. Hort. Sci. 49:241-255.

Reynard, G.B. 1960. Breeding tomatoes for resistance to fruit cracking. Proc. Plant Sci. Symp. Campbell Soup Co., Camden, N.J. p. 93-112.

Roberts, C.R., D.E. Knavel, J. Hartman, R. Scheibner, J. Herron, S. Allen, and H. Love. 1980 Commercial pepper production in Kentucky. Coop. Ext. Ser., Univ. of Kentucky, Lexington.

Satterwaite, F.E. 1946. An approximate distribution of estimates of variance components. Biomet. Bul. 2: 110-1 14.

Setiamihardja, R. 1982. Inheritance of certain fruit characters in Capsicum annuum $\mathrm{L}$. relative to the fruit detachment force. PhD Diss., Univ. of Kentucky, Lexington.

Singh, R.K. and B.D. Chandhory. 1979. Biometrical methods in quantitative genetic analysis. Kalyani, Ludhiana, India.

Shutak, V. and A.L. Schrader. 1948. Factors associated with skincracking of 'York Imperial' apples. Proc. Amer. Soc. Hort. Sci. 51:245-257.

Skene, D.S. 1980. Growth stress during fruit development in 'Cox's Orange Pippin' apples. J. Hort. Sci. 55:27-32. 